Abd El-Aziz El-Sayed Fouda*1, Farid Ibrahem El-Dossoki?, Elham Awad Sello'

${ }^{1}$ El-Mansoura University, Department of Chemistry, Faculty of Science, El-Mansoura-35516, Egypt, ${ }^{2}$ Port Said University, Department of Chemistry, Faculty of Science, Port Said, Egypt
Scientific paper ISSN 0351-9465, E-ISSN 2466-2585 UDC: $665.7 .038 .5+615.24: 669.141$ doi: $10.5937 /$ zasmat $1903245 \mathrm{E}$

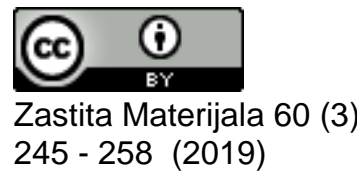

\title{
Esomeprazole Magnesium Trihydrate drug as a potential non-toxic corrosion inhibitor for mild steel in acidic media
}

\begin{abstract}
The inhibiting effect of Esomeprazole Magnesium Trihydrate drug on the corrosion of mild steel (MS) in $1 \mathrm{M} \mathrm{HCl}$ was performed by chemical tests (weight loss (WL)) and electrochemical methods (Tafel polarization (TP), electrochemical frequency modulation (EFM) and AC impedance spectroscopy (EIS)). The adsorption isotherm of Esomeprazole Magnesium Trihydrate drug on the MS surface was found to follow Temkin adsorption isotherm. Some thermodynamic parameters were computed and discussed. The obtained data showed that the inhibition efficiency (IE) rises with increasing the dose of the Esomeprazole Magnesium Trihydrate and with raising the temperature. The morphology of MS surface was analyzed by using scanning electron microscope (SEM), atomic force microscopy (AFM), and Fourier transforms infrared spectroscopy (FTIR) techniques. All test methods were in good agreement with each other.
\end{abstract}

Keywords: Acid corrosion, Mild steel, SEM, AFM, FTIR, Esomeprazole Magnesium trihydrate.

\section{INTRODUCTION}

Corrosion is an essential procedure playing a significant role in safety and economics , particularly for metals [1]. MS corrosion causes short shelf life, safety issues (hydrogen gas evolution), self-discharge and loss of valuable capacity, to reduce these undesirable effects, MS corrosion must be controlled [2]. Numerous inhibitors in utilized are either synthesized from cheap raw material or chosen from composite having heteroatoms in their aromatic or long-chain carbon system [3-4]. The studies prove that the inhibition influence of these organic composite occurring by its adsorption on surface of MS. Organic heterocyclic composite have utilized for the corrosion inhibition of carbon steel (CS) [5-13], copper [14], aluminum [15-17], and other metals $[18,19]$ in various aqueous solution. The drug adsorbed assisted to protect the metal surface [2022]. The select of some medication for inhibitor of corrosion is taking due to contain active centers, ecofriendly environmentally and simply purified and formed [23].

\footnotetext{
${ }^{*}$ Corresponding author: Abd El-Aziz El-Sayed Fouda E-mail: asfouda@hotmail.com

Paper received: 25. 04. 2019.

Paper accepted: 26. 05. 2019.

Paper is available on the website:

www.idk.org.rs/journal
}

In recent years, the drugs were utilized as corrosion inhibitors for different metals as result to their high solubility in water, with high molecular size and containing electronegative atoms such as $\mathrm{N}, \mathrm{O} \mathrm{S}$ atoms in their molecules and nontoxic nature of these compounds should be good corrosion inhibitors [24,25]. Adsorption of the drug molecules on the metal surface facilitates its inhibition [26-37].

The scope of this paper is to examine the inhibitive effect of Esomeprazole Magnesium Trihydrate towards the corrosion of $\mathrm{MS}$ in $1 \mathrm{M} \mathrm{HCl}$ utilizing electrochemical and non-electrochemical tests. The surface examination of the MS specimens was also analyzed.

\section{MATERIALS AND METHODS}

\subsection{Metal Sample}

MS contain of iron alloyed with less than $0.3 \%$ C, most commonly among 0.1 to $0.25 \%$. The building industry always utilized MS in construction due to its ductility and malleability ( $\mathrm{Fe}=99.77 \%$, $\mathrm{C}=0.06495$ ).

\subsection{Chemicals}

Inhibitor - Esomeprazole Magnesium Trihydrate is the investigated drug which has been used as inhibitor. Absolute ethanol (99\%) were supplied from Gamhoria Company and used for the preparation of ethanolic-aqueous mixtures with bidistilled water. 

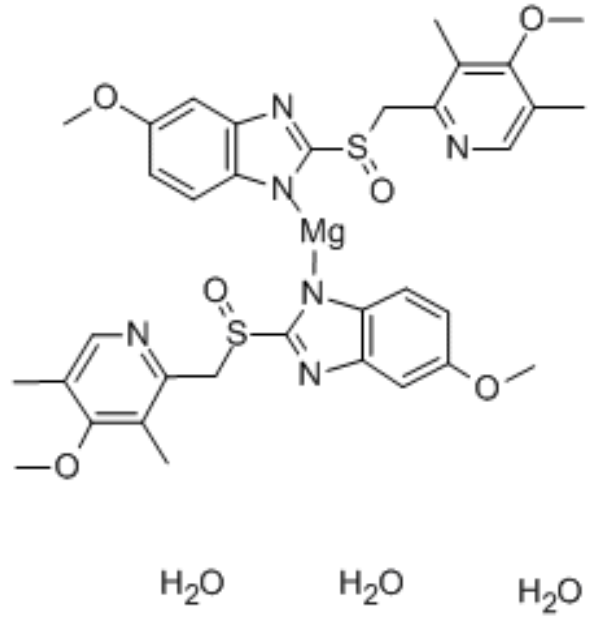

Magnesium,5-methoxy-2-[(4-methoxy-3,5dimethylpyridin-2-yl)methylsulfinyl] benzimidazol-1ide;trihydrate $\mathrm{C}_{34} \mathrm{H}_{42} \mathrm{MgN}_{6} \mathrm{O}_{9} \mathrm{~S}_{2}$, $M . W t=767.168 \mathrm{~g} / \mathrm{mol}$

\subsection{Solutions}

The aggressive solution was $1 \mathrm{M} \mathrm{HCl}$. Solutions of Esomeprazole Magnesium Trihydrate in ethanolwater mixed solvents with different ethanol mole fractions ( $x_{1}=0$ to 1.0 by weight) were prepared for density and refractive index measurements.

\subsection{Weight Loss (WL) Measurements}

For WL tests, square coins of surface area 2.6 $x 2.8 \mathrm{~cm}$ were exposed to the corrosive medium for $3 \mathrm{~h}$. The coins have abraded with emery papers with grit sizes (250,600 and 2000) and cleaned with acetone and finally dried by filter papers. The WL tests have taken in $100 \mathrm{~mL}$ glass beaker. The coins were then immediately immersed in the test solution with and without various doses of the investigated drug and all dipped in a water thermostat. The average WL for MS coins will achieve. The (\%IE) and the $(\theta)$ of Esomeprazole Magnesium Trihydrate for the corrosion of MS were measured as next [38]:

$$
\% I E=\theta \times 100=\left[1-\left(W / W^{0}\right)\right] \times 100
$$

where $\mathrm{W}^{0}$ and $\mathrm{W}$ are the $\mathrm{WL}$ with and without adding various doses of investigate drug, correspondingly.

\subsection{Electrochemical Measurements}

Potentiodynamic polarization (PP) method was taken in a typical three compartments glass cell [39]. The potential range was $(-800$ to $+200 \mathrm{mV}$ vs. SCE) at OCP with a scan rate $1 \mathrm{mVs}^{-1}$. Then $\mathrm{i}_{\text {corr }}$ was calculated for the measurements and was used to calculate the \%IE and the $\theta$ from Eq. (2) as below:

IE $\%=\theta \times 100=\left[1-\left(i_{\text {corr }(\text { inh })} / i_{\text {corr }(\text { free }}\right)\right] \times 100$ where $\mathrm{i}_{\text {corr(free) }}$ and $\mathrm{i}_{\text {corr(inh) }}$ are the current densities in the absence and presence of Esomeprazole Magnesium Trihydrate, correspondingly.

Impedance measurements were done by $A C$ signs of $10 \mathrm{mV}$ peak-to-peak amplitude and at a range of frequency of $10^{7} \mathrm{~Hz}$ to $0.1 \mathrm{~Hz}$ [40]. The capacitance of the double layer $\mathrm{C}_{\mathrm{dl}},(\% \mathrm{IE})$ and $\theta$ were founded from Eqs. (3) \& (4) which are defined as:

$$
C_{d l}=1 /\left(2 \pi f_{\max } R_{c t}\right)
$$

where $f_{\max }$ is the maximum frequency

$$
\text { IE \% }=\theta \times 100=\left[1-\left(R_{c t}^{\circ} / R_{c t}\right)\right] \times 100
$$

where $R_{c t}^{\circ}$ and $R_{c t}$ are the charge transfer resistances without and with drug, respectively.

EFM technique used two frequencies of range 2 and $5 \mathrm{~Hz}$ depending on three conditions. The ( $\left.i_{\text {corr }}\right), \quad\left(\beta_{c}\right.$ and $\left.\beta_{\mathrm{a}}\right)$ and (CF-2, CF-3) (Causality factors) [41] were measured by the higher two peaks. The \% IE $E_{E F M}$ was calculated as in Eq. (2)

(TP), (EFM) and (EIS) techniques were performed utilizing the similar manner as earlier with a Gamry framework system rely on ESA400. Gamry apparatus includes software EFM140 for EFM tests and EIS300 for EIS method; the computer has used for summation value. Echem Analyst 5.5 Software had utilized for drawing and fitting data.

\subsection{Surface Examinations}

The MS coins utilized for analysis of morphology surface were set in $1 \mathrm{M} \mathrm{HCl}$ acid (blank) and in presence of $30 \mathrm{ppm}$ of Esomeprazole Magnesium Trihydrate at room temperature for one day after abraded mechanically utilizing various emery papers up to 1200 grit size. Then, after this exposure time, the examination was carried out by utilizing (SEM), AFM and FTIR tests.

\section{RESULTS AND DISCUSSION}

\subsection{Weight Loss (WL) Measurement}

Weight loss of $\mathrm{MS}$, in $\mathrm{mg} \mathrm{cm} \mathrm{cm}^{-2}$ of the surface area, was measured at different time periods with and without various doses (10-60 ppm) of the Esomeprazole Magnesium Trihydrate. The curves obtained with different doses of drug fall considerably below that of free acid as shown in Figure 1. The \% IE's are recorded in Table 1. In all cases, the efficiency of the drug was improved with raising doses of the Esomeprazole Magnesium Trihydrate and the rate of corrosion was lowered. These results indicated that, the Esomeprazole Magnesium Trihydrate is good efficient inhibitor for MS dissolution in $\mathrm{HCl}$ solution. 


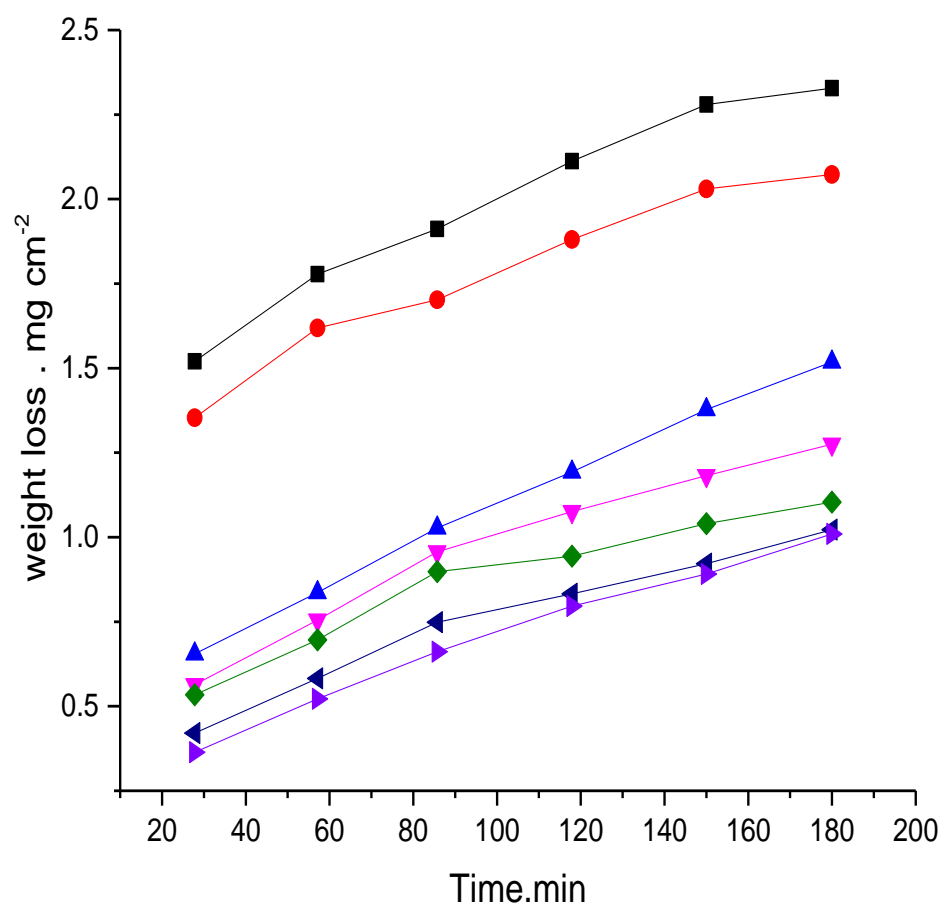

Figure 1. WL-time diagrams for the MS in $0.5 \mathrm{M} \mathrm{HCl}$ without and with various doses of Esomeprazole Magnesium Trihydrate at $25^{\circ} \mathrm{C}$

Slika 1. Dijagrami $W L$ - vreme za $M S$ u $0,5 \mathrm{M} \mathrm{HCl}$ bez i sa različitim dozama Esomeprazole Magnesium Trihydrate na $25^{\circ} \mathrm{C}$

Table 1. \%IE of different doses of Esomeprazole Magnesium Trihydrate at different temperatures after 120 min exposed in $1 \mathrm{M}$ $\mathrm{HCl}$ solution

Tabela 1. \%IE različitih doza Esomeprazole Magnesium Trihydrate na različitim temperaturama nakon $120 \mathrm{~min}$ izloženo $u 1 \mathrm{M}$ rastvoru $\mathrm{HCl}$

\begin{tabular}{|c|c|c|c|c|c|}
\hline \multirow{2}{*}{ Conc., ppm } & \multicolumn{5}{|c|}{$\% \mathrm{IE}$} \\
\cline { 2 - 6 } & $25^{\circ} \mathrm{C}$ & $35^{\circ} \mathrm{C}$ & $45^{\circ} \mathrm{C}$ & $55^{\circ} \mathrm{C}$ & $65^{\circ} \mathrm{C}$ \\
\hline 10 & 30.9 & 77.5 & 80.2 & 83.6 & 85.5 \\
\hline 20 & 48.0 & 79.8 & 82.5 & 87.4 & 91.6 \\
\hline 30 & 49.0 & 80.7 & 83.4 & 88.2 & 91.7 \\
\hline 40 & 55.3 & 82.2 & 85.2 & 90.1 & 92.2 \\
\hline 50 & 60.5 & 82.8 & 87.8 & 91.5 & 93.4 \\
\hline 60 & 68.0 & 85.4 & 89.4 & 92.0 & 93.2 \\
\hline
\end{tabular}

\subsection{Adsorption Isotherms}

The adsorption isotherms were used to explain the adsorption mechanism of the inhibitors on the metal surfaces. The best fitting isotherm for our data is the Temkin isotherm. Figure 2 shows the plotting of $\theta$ against $\log \mathrm{C}$ at $25^{\circ} \mathrm{C}$ for Esomeprazole Magnesium trihydrate drug. This plot gave straight lines indicating that the adsorption of Esomeprazole Magnesium Trihydrate on MS surface obeys Temkin isotherm:

$$
\Theta=(1 / f) \ln K_{a d s} C
$$

$\mathrm{C}_{\text {inh }}$ is the inhibitor dose, $\mathrm{K}_{\mathrm{ads}}$ is the adsorption equilibrium constant, and "a" is a parameter of lateral interaction which describes the molecular interactions in the adsorbed layer

Table 2. Temkin adsorption isotherm of Esomeprazole Magnesium Trihydrate drug on MS surface in $1 \mathrm{M} \mathrm{HCl}$ at various temperatures

Tabela 2. Temkinove adsorpcione izoterme leka Esomeprazole Magnesium Trihydrate na površini $\mathrm{MS}$ u $1 \mathrm{M} \mathrm{HCl}$ pri različitim temperaturama

\begin{tabular}{|c|c|c|c|c|}
\hline $\begin{array}{l}\text { Temp } \\
\stackrel{\circ}{ } \mathrm{C}\end{array}$ & a & $\begin{array}{l}-\Delta \mathrm{G}^{\circ}{ }_{\mathrm{ads}}, \\
\mathrm{kJ} \mathrm{mol}\end{array}$ & $\begin{array}{c}\Delta \mathrm{H}^{\circ} \text { ads } \\
\mathrm{kJ} \mathrm{mol}^{1}\end{array}$ & $\begin{array}{c}\Delta \mathrm{S}_{\text {ads }} \\
J \mathrm{~mol}^{1} K^{1}\end{array}$ \\
\hline 25 & 12.5 & 29.7 & \multirow{5}{*}{49} & 99 \\
\hline 35 & 11.9 & 35.3 & & 114 \\
\hline 45 & 10.8 & 36.6 & & 115 \\
\hline 55 & 10.9 & 39.6 & & 120 \\
\hline 65 & 10.5 & 40.8 & & 121 \\
\hline
\end{tabular}




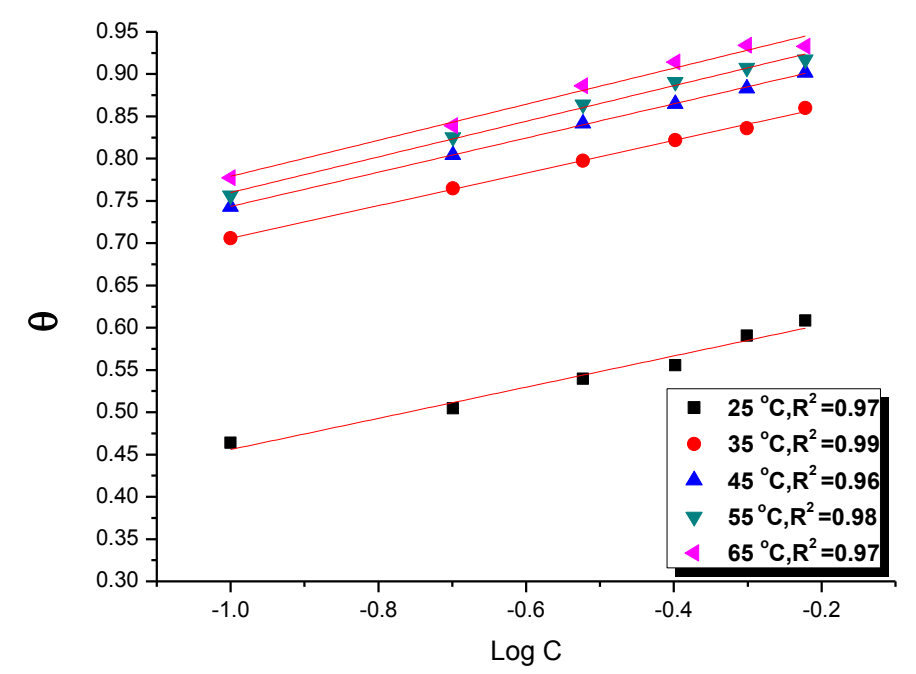

Figure.2. Temkin curves of Esomeprazole Magnesium Trihydrate on $\mathrm{MS}$ in $\mathrm{HCl}$ at various temperatures

Slika 2. Temkinove krive leka Esomeprazole Magnesium Trihydrate na MS u HCl pri različitim temperaturama

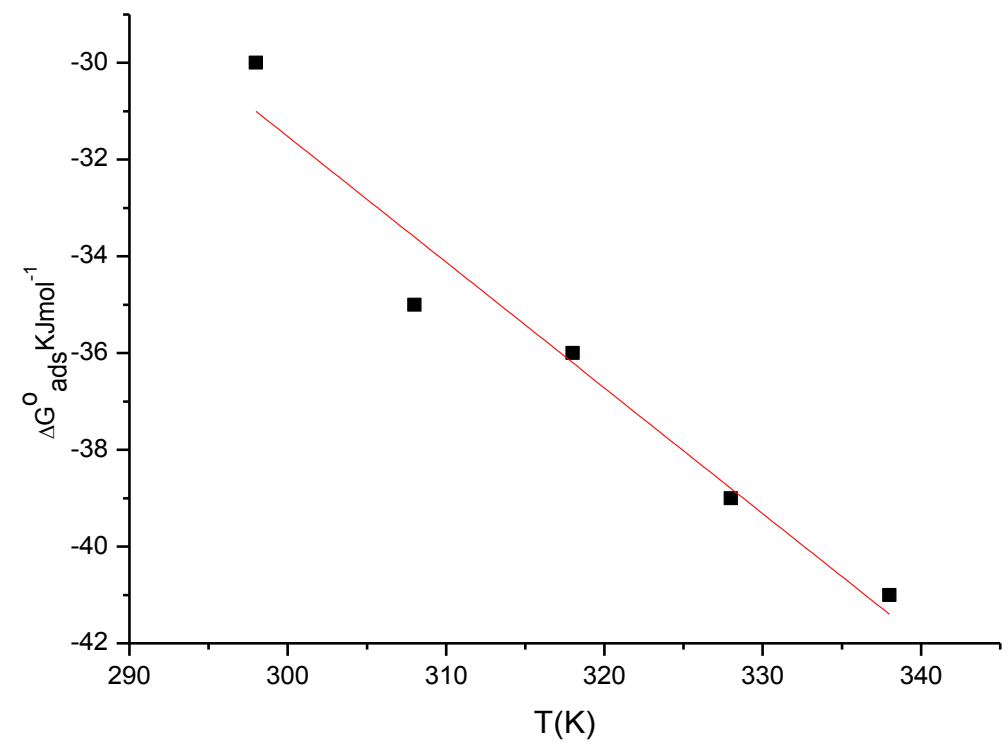

Figure 3. Curve $\Delta G^{\circ}{ }_{\text {dds }}$ vs $(T)$ for corrosion of $M S$ in $1 \mathrm{M} \mathrm{HCl}$ in the presence of Esomeprazole Magnesium Trihydrate

Slika 3. Kriva $\triangle G \circ A D S$ vs (T) za koroziju MS u $1 M H C L$ u prisustvu Esomeprazole Magnesium Trihydrate

As reported in the literature if the value of $\Delta \mathrm{G}^{\circ}$ ads is between -20 and $-40 \mathrm{~kJ} \mathrm{~mol}^{-1}$ the adsorption of the inhibitor on the metal surface is mixed one (i.e. physisorption and chemisorption). So the adsorption of the investigated drug on MS surface is mixed one $\left(\Delta \mathrm{G}^{\circ}{ }_{\text {ads }}\right.$, between -20 and -40 $\mathrm{kJ} \mathrm{mol}^{-1}$ ). The negative sign data of $\Delta \mathrm{G}^{\circ}$ ads means that adsorption occurs spontaneously. The standard enthalpy $\Delta \mathrm{H}^{\circ}$ ads and $\Delta \mathrm{S}^{\circ}$ ads can be measured using the following Eq. (7):

$$
\Delta G^{\circ}{ }_{a d s}=\Delta H_{a d s}^{\circ}-T \Delta S^{\circ}{ }_{a d s}
$$

The $\Delta H^{\circ}$ ads data was evaluated from the intercept of the plot of $\Delta \mathrm{G}^{\circ}$ ads versus $T$ see Figure (3). The positive sign data of $\Delta \mathrm{H}^{\circ}$ ads ensures that the process of adsorption is an endothermic, the $\Delta S^{\circ}$ ads obtained from the slope of the line of Fig.3. The negative sign on $\Delta S^{\circ}$ ads indicates that the adsorption of the drug accompany by ordering of the drug on the MS surface. 


\subsection{Effect of Temperature}

WL tests were used to prove the temperature effect on MS corrosion rate ( $\left.k_{\text {corr }}\right)$ in Aggressive solution. Figure 1 shows WL of MS in corrosive solution with different Esomeprazole Magnesium Trihydrate doses at various temperatures (298338K). Table . 1 illustrate the adsorption is aided by raising the temperature. This performance demonstrates that the adsorption of inhibitors on MS surface happens among chemical adsorption. Ivanov [42], considers the rise of \% IE with temperature rise, MS chemisorption is preferred as higher temperature. Other authors [43-45] reported similar explanations.

\subsection{Kinetic-Thermodynamic Corrosion Parameter}

Activation energies for corrosion process $\left(\mathrm{E}_{\mathrm{a}}^{*}\right)$ were obtained from Arrhenius relation as follows:

$$
\log k_{\text {corr }}=\log A-\left(E_{a}^{*} / 2.303 R\right)(1 / T)
$$

where $A$ is constant, $R$ is universal gas constant, and $T$ is temperature in Kelvin [46-49]. Plots of log $\mathrm{k}_{\text {corr }}$ and 1000/T were illustrated in Figure 4. Enthalpy of activation for the corrosion process $\left(\Delta \mathrm{H}^{*}\right)$ and entropy of activation for corrosion process $\left(\Delta S^{*}\right)$ were determined by plotting log $\mathrm{k}_{\text {corr }} / \mathrm{T}$ against $1 / \mathrm{T}$ (Figure 5 ), according to the following equation:

$$
\begin{aligned}
& \log k_{\text {corr }} / T=\log \left(R / N h+\Delta S^{*} / 2.303 R\right)+ \\
& +\left(-\Delta H^{*} / 2.303 R\right)(1 / T)
\end{aligned}
$$

where $\mathrm{h}$ is constant and $\mathrm{N}$ is number of Avogadro. Increasing of $\mathrm{E}_{\mathrm{a}}^{*}$ and $\Delta \mathrm{H}^{*}$ with Esomeprazole
Magnesium Trihydrate was because energy barrier that created in existence of Esomeprazole Magnesium Trihydrate. $\Delta \mathrm{H}^{*}$ values were found to have positive signs, indicating anodic dissolution reaction of $\mathrm{MS}$. Negative $\Delta \mathrm{S}$ indicated that from reactants to the activated complex, the disorder lowered [50].

Figure 5 shows a plot of $\left(\log k_{\text {corr }}\right)$ against $(1 / T)$ in the case of inhibitor Esomeprazole Magnesium Trihydrate in $1 \mathrm{M} \mathrm{HCl}$. A straight line is obtained with a slope equals to $\left(\Delta \mathrm{H}^{*} / 2.303 \mathrm{R}\right)$ and the intercept is $\left[\log \left(R / N h+\Delta S^{*} / 2.303 R\right)\right]$ are calculated (Table 3).

Table 3. Parameters from activation process for MS in corrosive solution without and with various drug doses Esomeprazole Magnesium Trihydrate

Tabela 3. Parametri procesa aktiviranja za MS u korozivnom rastvoru bez i sa raznim dozama leka Esomeprazole Magnesium Trihydrate

\begin{tabular}{|c|c|c|c|}
\hline \multicolumn{3}{|c|}{ Activation parameters } & \multirow{2}{*}{$\begin{array}{c}\mathrm{C}_{\text {inh. }} \\
\mathrm{ppm}\end{array}$} \\
$\begin{array}{c}-\Delta \mathrm{S}^{*} \\
\left(\mathrm{~J} \mathrm{~mol}^{-1} \mathrm{~K}^{-1}\right)\end{array}$ & $\begin{array}{c}\Delta \mathrm{H}^{*} \\
\left(\mathrm{~kJ} \mathrm{~mol}^{-1}\right)\end{array}$ & $\begin{array}{c}\mathrm{E}_{\mathrm{a}}{ }^{*} \\
\left(\mathrm{~kJ} \mathrm{~mol}^{-1}\right)\end{array}$ & blank \\
\hline 167.5 & 32.7 & 58.8 & 10 \\
\hline 208 & 21.1 & 22.4 & 20 \\
\hline 223 & 17.7 & 19.3 & 30 \\
\hline 224 & 17.6 & 19.1 & 40 \\
\hline 226 & 17.4 & 19.0 & 50 \\
\hline 228 & 17.2 & 18.9 & 60 \\
\hline 229 & 17.2 & 18.8 & 6 \\
\hline
\end{tabular}

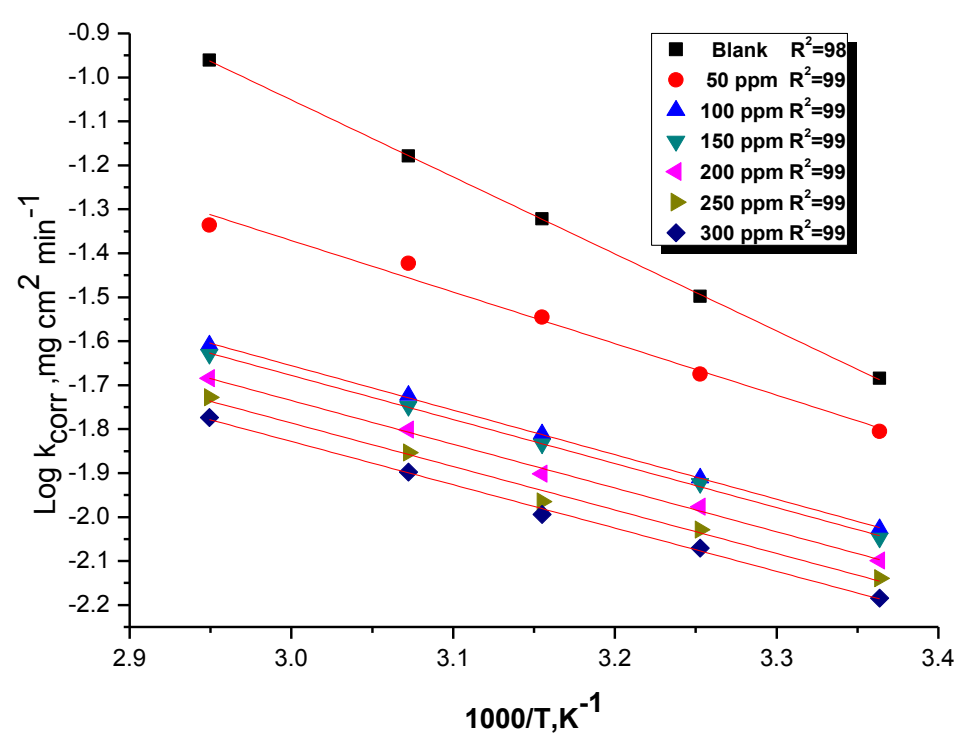

Figure 4. Curves (log $\left.k_{\text {corr }} / T\right)$ against $(1000 / T)$ in $1 \mathrm{M} \mathrm{HCl}$ without and with various doses of drug Esomeprazole Magnesium Trihydrate

Slika 4. Krive (log kcorr/T) prema (1000/T) u $1 \mathrm{M} \mathrm{HCl} \mathrm{bez} \mathrm{i} \mathrm{sa} \mathrm{raznim} \mathrm{dozama} \mathrm{leka} \mathrm{Esomeprazole}$ Magnesium Trihydrate 


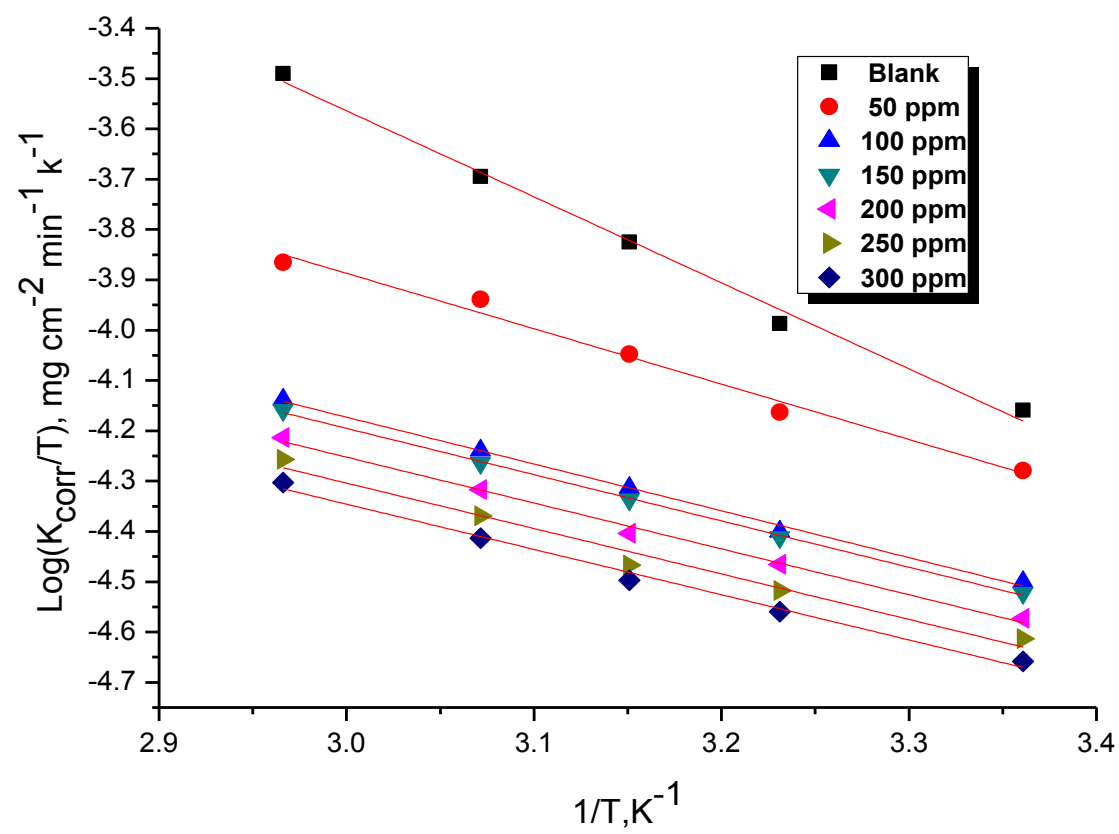

Figure 5. Log $\left(k_{\text {corr }} / T\right)$ vs $(1000 / T)$ curves for MS immersed in $1 \mathrm{M} \mathrm{HCl}$ with and without various doses of the drug Esomeprazole Magnesium Trihydrate

Slika 5. Krive Log (kcorr/T) vs (1000/T) krive za MS uronjene u $1 \mathrm{M} \mathrm{HCl}$ sa i bez različitih doza leka Esomeprazole Magnesium Trihydrate

\subsection{Electrochemical Frequency Modulation (EFM) Measurements}

EFM is characterized by speed and greatly accuracy in calculating the current data $[51,52]$. Figure 6 indicate the EFM of MS in $1 \mathrm{M} \mathrm{HCl}$ solution and at $30 \mathrm{ppm}$ of Esomeprazole Magnesium Trihydrate drug. The EFM parameters such as (CF-
2 and CF-3), ( $\beta_{c}$ and $\beta_{a}$ ) and (icorr) can be measured from the higher current peaks (Tabel 4). The CF is closer to the standard data proved the validity of the calculated data. The IE\% increase with the raising of Esomeprazole Magnesium Trihydrate doses. The \% IE $E_{E F M}$ rise by raising the drug doses and was measured as in Eq. (2)

Table 4. Parameters of EFM diagrams for MS corrosion without and with various doses of the drug Esomeprazole Magnesium Trihydrate in $1 \mathrm{M} \mathrm{HCl}$ at $25^{\circ} \mathrm{C}$

Tabela 4. Parametri EFM dijagrama za koroziju MS bez i sa raznim dozama leka Esomeprazole Magnesium Trihydrate u $1 \mathrm{M} \mathrm{HCl}$ na $25^{\circ} \mathrm{C}$

\begin{tabular}{|c|c|c|c|c|c|c|c|c|}
\hline$\%$ IE & $\ominus$ & CF3 & CF2 & CR mpy & $\beta_{\mathrm{c}} \mathrm{mV} / \mathrm{dec}$ & $\beta_{\mathrm{a}} \mathrm{mV} / \mathrm{deade}$ & $\begin{array}{c}\mathrm{i}_{\text {corr }} \\
\mathrm{uA}\end{array}$ & \\
\hline & & 2.7 & 1.7 & 192.10 & 92 & 86 & 420.4 & blank \\
\hline 55.7 & 0.557 & 1.50 & 2.90 & 49 & 126 & 114 & 186 & 5 \\
\hline 59 & 0.59 & 1.90 & 2.27 & 57.80 & 121 & 107 & 172.2 & 10 \\
\hline 72.8 & 0.728 & 2.40 & 2.80 & 57.1 & 12.3 & 110 & 114.1 & 15 \\
\hline 76.5 & 0.765 & 1.89 & 2.21 & 45.02 & 879 & 82 & 98.76 & 20 \\
\hline 72.8 & 0.728 & 1.98 & 2.47 & 43.20 & 735 & 71 & 81.99 & 25 \\
\hline 80.5 & 0.805 & 2.19 & 2.07 & 39.91 & 59.1 & 56 & 57.67 & 30 \\
\hline
\end{tabular}



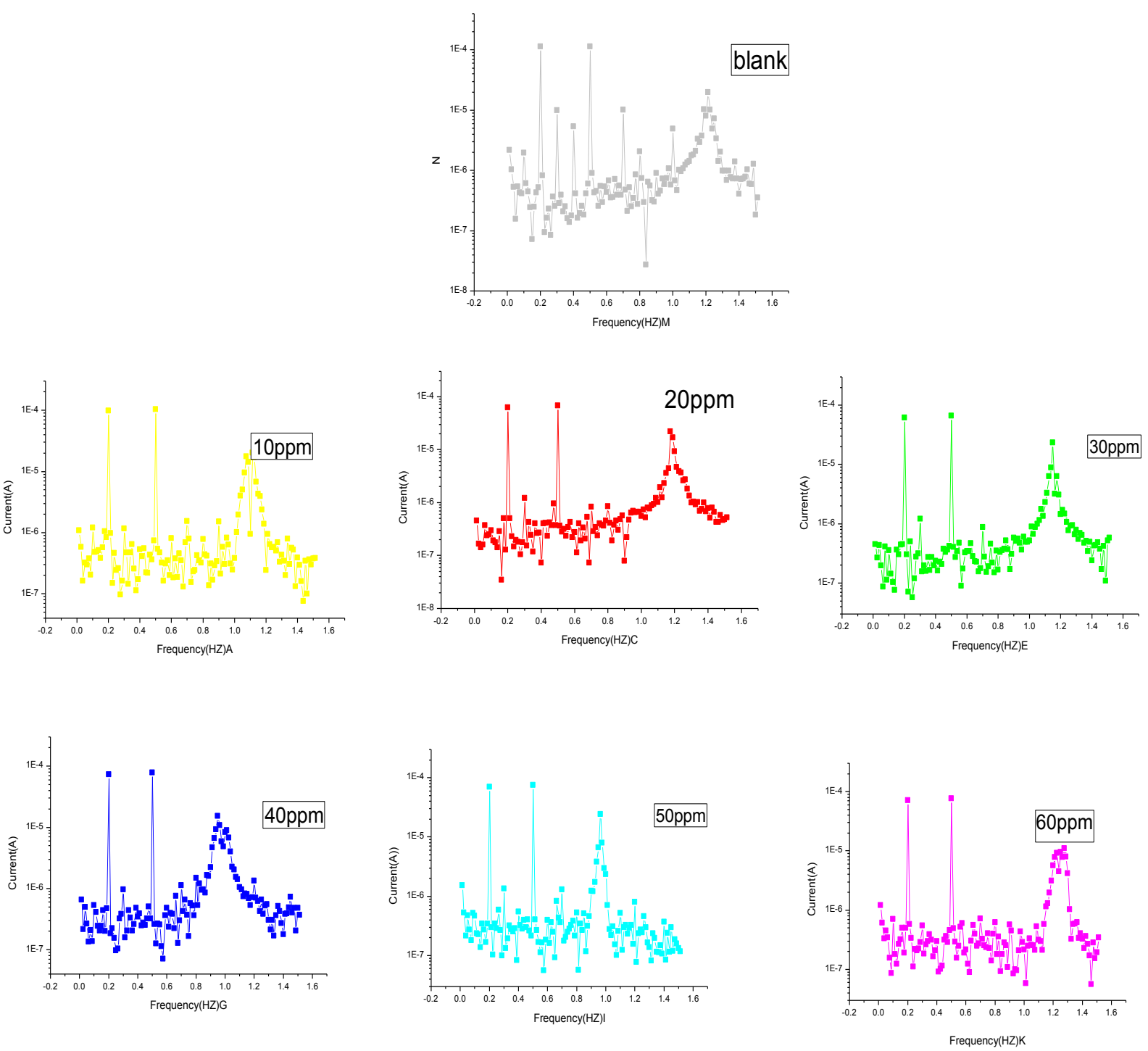

Figure 6. EFM spectra for MS in $1 \mathrm{M} \mathrm{HCl}$ (blank) and the presence of various doses of the drug Esomeprazole Magnesium Trihydrate

Slika 6. EFM spektar za MS u $1 \mathrm{M} \mathrm{HCl}$ (prazan) i prisustvo različitih doza leka Esomeprazole Magnesium Trihydrate

\subsection{Electrochemical Impedance Spectroscopy (EIS) Measurements}

Both Nyquist and Bode bends for MS corrosion in $1 \mathrm{M} \mathrm{HCl}$ only and also in acid in existence of varied dose of Esomeprazole Magnesium Trihydrate were obtained by EIS procedure and shown in Figure $7(a, b)$. It is noticed from Nyquist figure that the curves appear semicircular. The frequency dispersion is responsible for the shape of the curve. The special shape of the Nyquist curves confirms that the MS corrosion is controlled by charge transfer process [53]. It was found that in the Nyquist diagrams the existence of inhibitor leads to raise the diameter of capacitive loop.
Charge transfer resistance $\left(R_{c t}\right)$ is responsible for high frequency capacitive loop. The double layer capacitance $\left(C_{d l}\right)$ is the frequency at which the component of the impedance is maximum and could be measured according to the next equation:

$$
C_{d l}=1 / 2 \pi \quad F_{\max } R_{c t}
$$

where $R_{c t}$ is the charge transfer resistance and $f$ is the frequency at the maximum altitude of the semicircle. The parameters obtained by EIS procedure was report in (Table 5). Figure 8 showed the fiting equivalent circuit for EIS data, which consists solution resistance $\left(R_{s}\right)$, resistance charge transfer $\left(R_{\mathrm{ct}}\right)$, and a CPE instead of a pure 
capacitor signifying the interfacial capacitance. From the results calculated, it was observe that the $R_{c t}$ values increases with increasing Esomeprazole Magnesium Trihydrate dose but $\mathrm{C}_{\mathrm{dl}}$ data lowered. The adsorption of Esomeprazole Magnesium
Trihydrate on the MS surface leads to this result. The results obtain proves that the Esomeprazole Magnesium Trihydrate works by forming the protective layer on the MS surface which modifies the MS/acid interface.

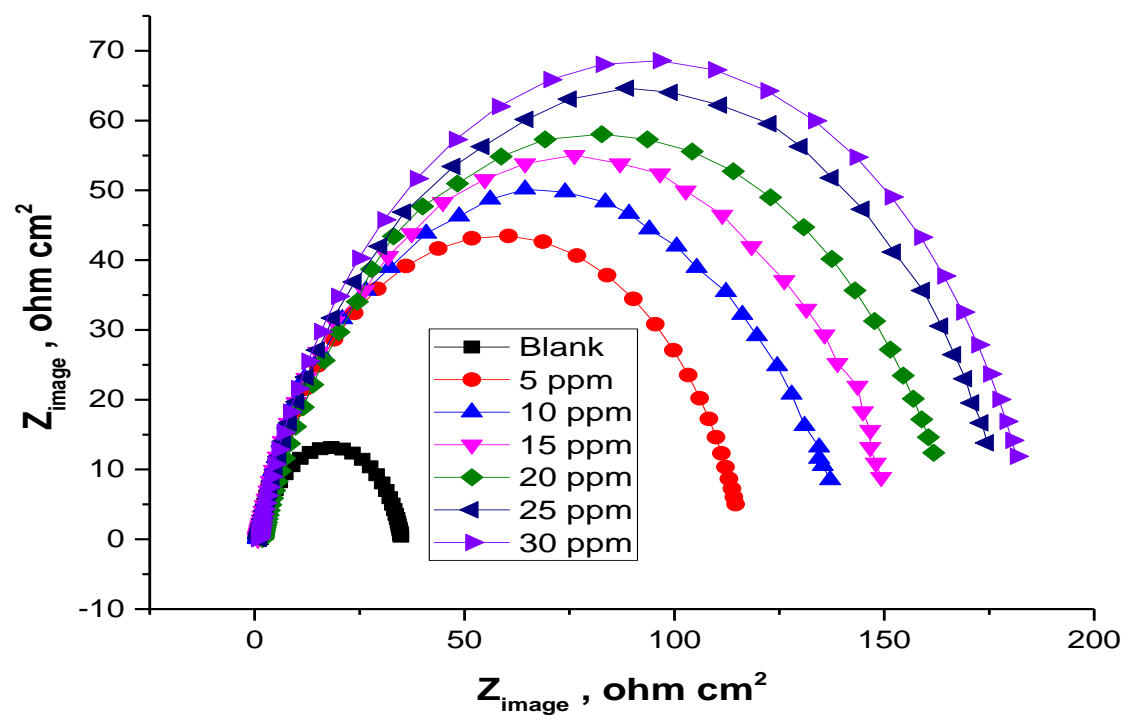

Figure 7a. Nyquist curves for the $\mathrm{MS}$ corrosion in $1 \mathrm{M} \mathrm{HCl}$ with and without various doses of the drug Esomeprazole Magnesium Trihydrate at $25^{\circ} \mathrm{C}$

Slika 7a. Nyquist krive za MS koroziju u $1 \mathrm{M} \mathrm{HCl} \mathrm{sa} \mathrm{i} \mathrm{bez} \mathrm{različitih} \mathrm{doza} \mathrm{leka} \mathrm{Esomeprazole} \mathrm{Magnesium}$ Trihydrate na $25^{\circ} \mathrm{C}$

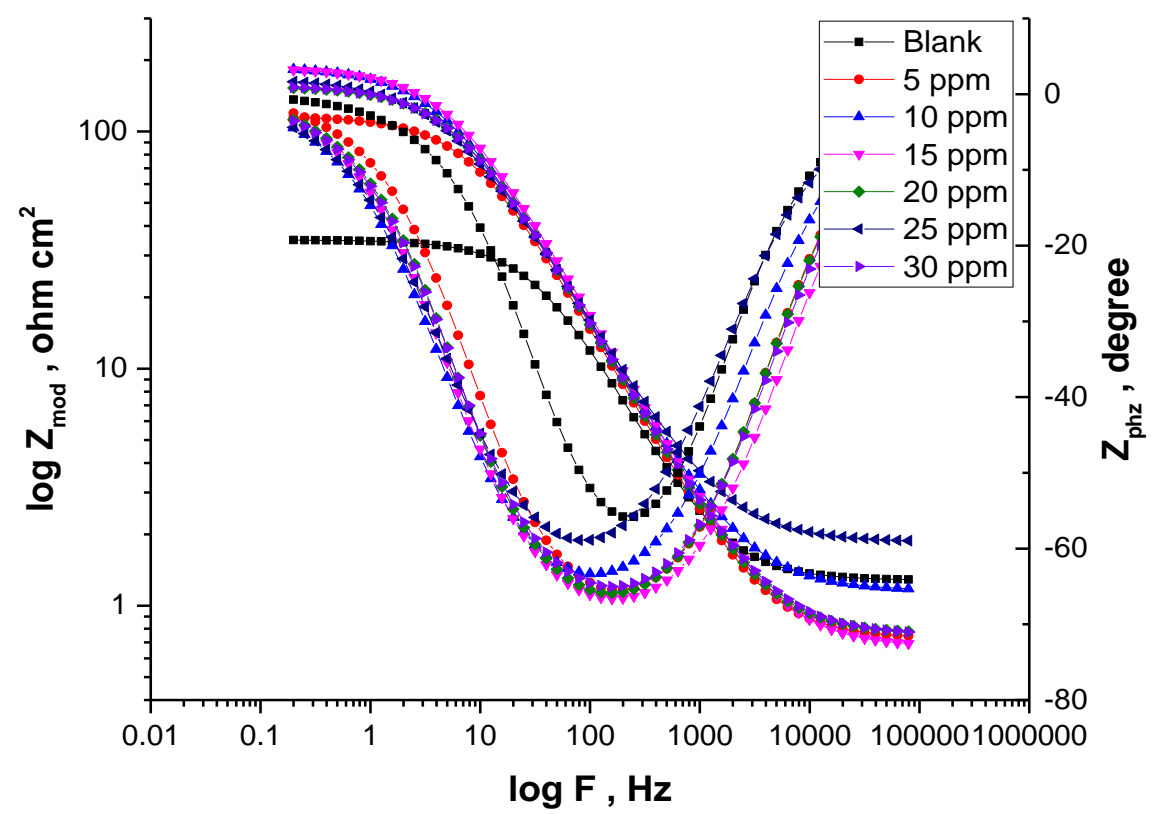

Figure $7 b$. The Bode curves for the corrosion of $M S$ in $1 \mathrm{M} \mathrm{HCl}$ with and without various doses of Esomeprazole Magnesium Trihydrate at $25^{\circ} \mathrm{C}$

Slika 7b. Bode-krive za koroziju MS u $1 \mathrm{M} \mathrm{HCl}$ sa i bez različitih doza Esomeprazole Magnesium Trihydrate at $25^{\circ} \mathrm{C}$ 
Table 5 The obtained data from EIS tests for MS in $1 \mathrm{M} \mathrm{HCl}$ with and without various doses of Esomeprazole Magnesium Trihydrate

Tabela 5. Dobijeni podaci iz EIS testova za MS u $1 \mathrm{M} \mathrm{HCl}$ sa $i$ bez različitih doza Esomeprazole Magnesium Trihydrate

\begin{tabular}{|c|c|c|c|c|}
\hline$\%$ IE & $\Theta$ & $\mathrm{C}_{\mathrm{dl}}$ & $\mathrm{R}_{\mathrm{ct}}$, ohm cm & Conc., $\mathrm{ppm}$ \\
\hline---- & ---- & 237 & 33.7 & blank \\
\hline 70.8 & 0.708 & 200 & 115.4 & 5 \\
\hline 78.2 & 0.782 & 191 & 154.8 & 10 \\
\hline 78.5 & 0.785 & 176 & 156.4 & 15 \\
\hline 79.6 & 0.796 & 172 & 165.6 & 20 \\
\hline 81.8 & 0.818 & 165 & 185.3 & 25 \\
\hline 82.0 & 0.820 & 162 & 187.3 & 30 \\
\hline
\end{tabular}

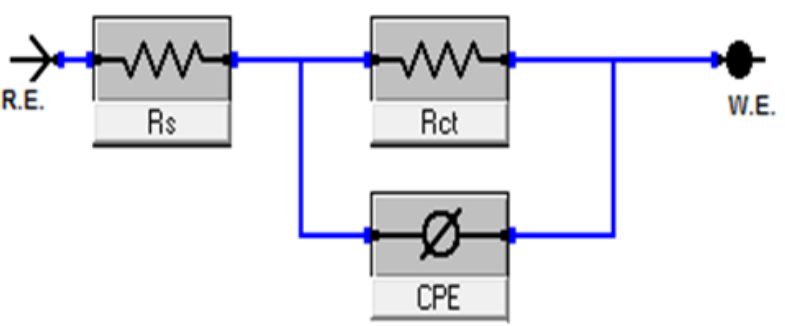

Figure 8. Circuit applied to fit the impedance data Slika 8. Strujno kolo primenjeno za ispitivanje impedance

\subsection{Tafel Polarization (TP) Measurements}

Figure 9 shows Tafel plots at $25^{\circ} \mathrm{C}$ for MS in corrosive solution without and with many Esomeprazole Magnesium Trihydrate concentrations. As indicated from the figure, increasing Esomeprazole Magnesium Trihydrate concentration leads to decrease cathodic " $\mathrm{H}_{2}$ reduction" and anodic "metal dissolution" reactions. This behavior illustrated that a mixed type inhibitor mechanisms are present. \%IE and $\theta$ from TP tests were

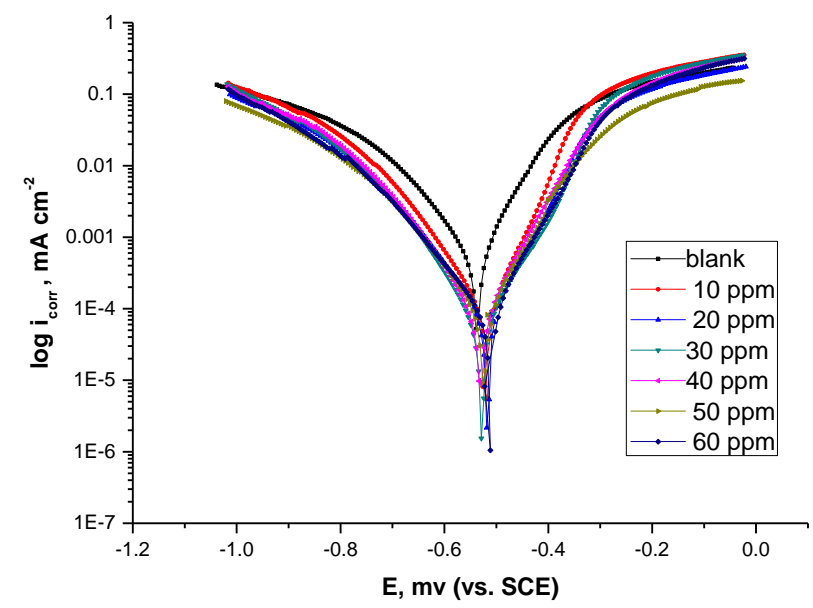

Figure 9. Tafel plots for CS in corrosive solution without and with different doses of the drug Esomeprazole Magnesium Trihydrate at $25^{\circ} \mathrm{C}$

Slika 9. Tafelove krive za CS u korozivnom rastvoru bez i sa različitim dozama leka Esomeprazole Magnesium Trihydrate na $25^{\circ} \mathrm{C}$

Table 6. $i_{\text {corr }}, E_{\text {corr }}, \beta_{c,}, \beta_{a}, k_{\text {corr }} \theta$, and \%IE for CS in the corrosive solution without and with different doses of the drug Esomeprazole Magnesium Trihydrate

Tabela 6. $i_{c o r r}, E_{c o r r}, \beta_{c,} \beta_{a}, k_{\text {corr }} \theta i$ \%IE za CS u korozivnom rastvoru bez $i$ sa različitim dozama leka Esomeprazole Magnesium Trihydrate

\begin{tabular}{|c|c|c|c|c|c|c|c|}
\hline$\% \mathrm{IE}$ & $\Theta$ & $\mathrm{C} \mathrm{R} \mathrm{mpy}$ & $\beta_{\mathrm{c}} \mathrm{mV} \mathrm{dec}$ & $\beta_{\mathrm{a}} \mathrm{mV} \mathrm{dec}^{-1}$ & $-\mathrm{E}_{\text {corr }} \mathrm{mV}$ vs SCE & $\mathrm{i}_{\text {corr }} \mu \mathrm{A} \mathrm{cm}^{-2}$ & Conc., $\mathrm{ppm}$ \\
\hline---- & ---- & 261.7 & 118 & 81 & 573 & 542.0 & blank \\
\hline 82.9 & 0.829 & 42.4 & 115 & 85 & 542 & 92.8 & 5 \\
\hline 84.1 & 0.841 & 39.4 & 110 & 82 & 530 & 86.2 & 10 \\
\hline 88.4 & 0.884 & 28.7 & 105 & 74 & 518 & 62.9 & 15 \\
\hline 89.7 & 0.897 & 25.4 & 103 & 84 & 529 & 41.3 & 20 \\
\hline 92.4 & 0.924 & 18.8 & 108 & 68 & 512 & 35.8 & 30 \\
\hline 93.4 & 0.934 & 16.3 & 74 & 54 & 521 & & 30 \\
\hline
\end{tabular}




\subsection{SEM Analysis}

Figure 10a-c shows MS after surface treatment before electrochemical measurements; 10b after corrosion in $\mathrm{HCl}$ without and 10c with addition of 30 ppm Esomeprazole Magnesium Trihydrate. Presence of Esomeprazole Magnesium Trihydrate minimizes corrosion surface damage and make surface smoother of MS. This might be due to formation of a passive layer through Esomeprazole Magnesium Trihydrate adsorption on the MS surface that blocks the active sites and minimizes metal contact with corrosive solution.

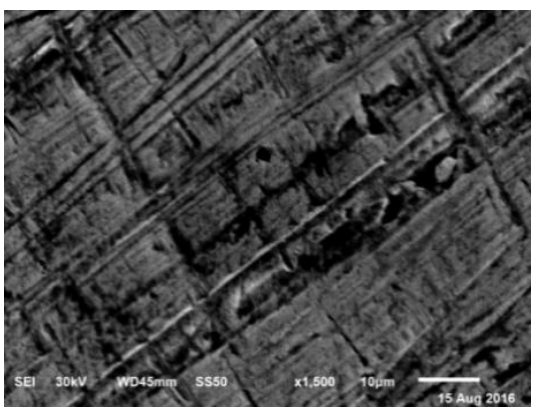

(a) Free sample

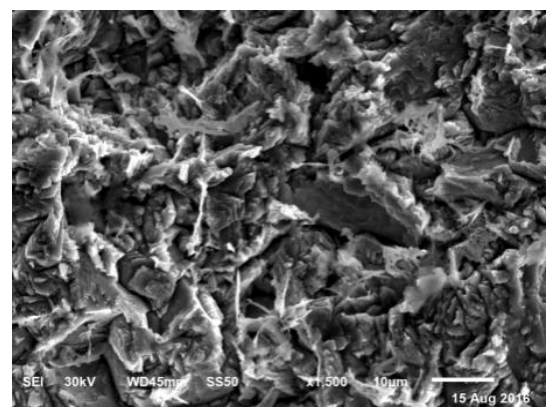

(b) Blank

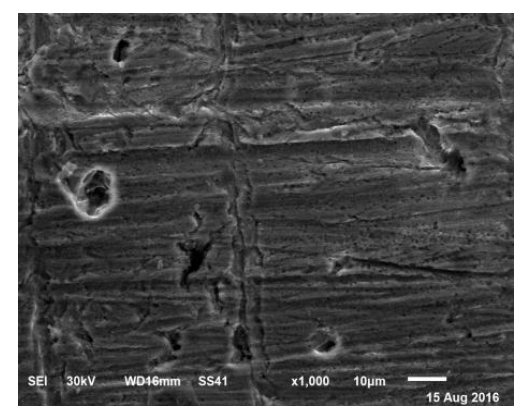

c) $1 \mathrm{M} \mathrm{HCl}+30 p p m$ of

Esomeprazole Magnesium Trihydrate

Figure. 10. SEM micrographs for MS with and without of $30 \mathrm{ppm}$ of drug Esomeprazole Magnesium Trihydrate after immersion for one day

Slika 10. SEM mikrografije za MS sa i bez 30 ppm leka Esomeprazole Magnesium Trihydrate nakon potapanja tokom jednog dana

\subsection{Atomic Force Microscopy (AFM) Analysis}

AFM is a remarkable technique used for measuring the surface roughness with high resolution. Many details about MS surface morphology can be obtained from AFM measurements which help explaining the corrosion process. The three dimensional AFM images were represented in Figure 11.

The mean roughness is given (17.67) nm for MS free, $(553 \mathrm{~nm})$ for the blank in acid solution which dipped for one day and then examined. The

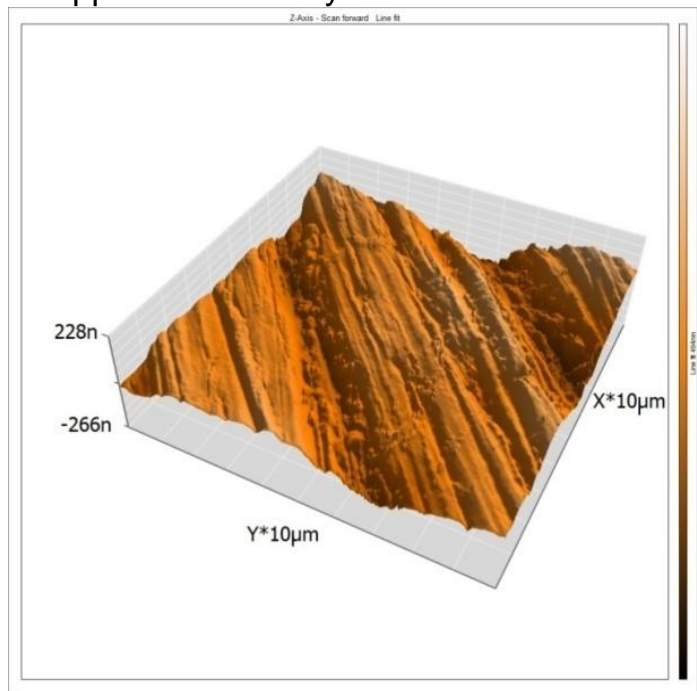

(a) Free observation of the MS surface which dipped in $1 \mathrm{M}$ $\mathrm{HCl}$ in existence of $30 \mathrm{ppm}$ of Esomeprazole Magnesium Trihydrate given (332 nm) compared to the blank solution. The values showed that the roughness rises with adding $\mathrm{HCl}$ due to the corrosion occurs on the MS surface but decreased with adding the Esomeprazole Magnesium Trihydrate [54] due to the formation of a film of drug on MS surface.

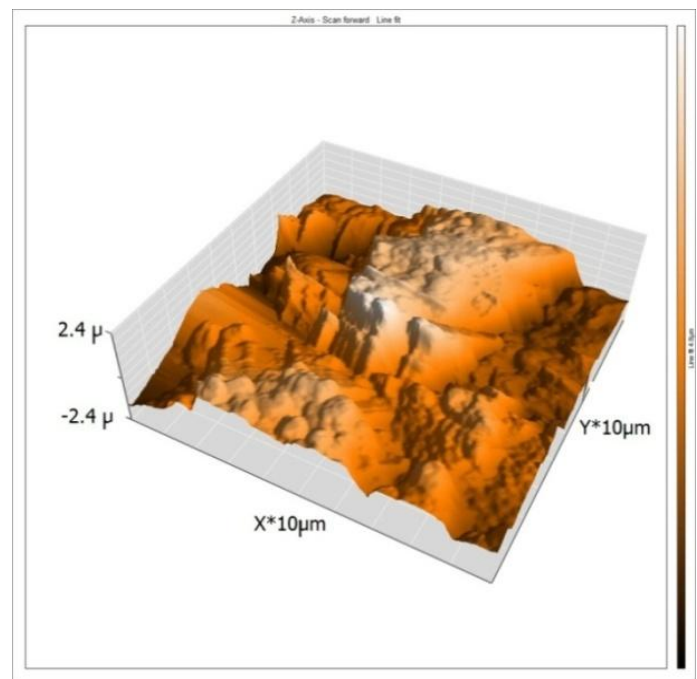

(b) Blank 


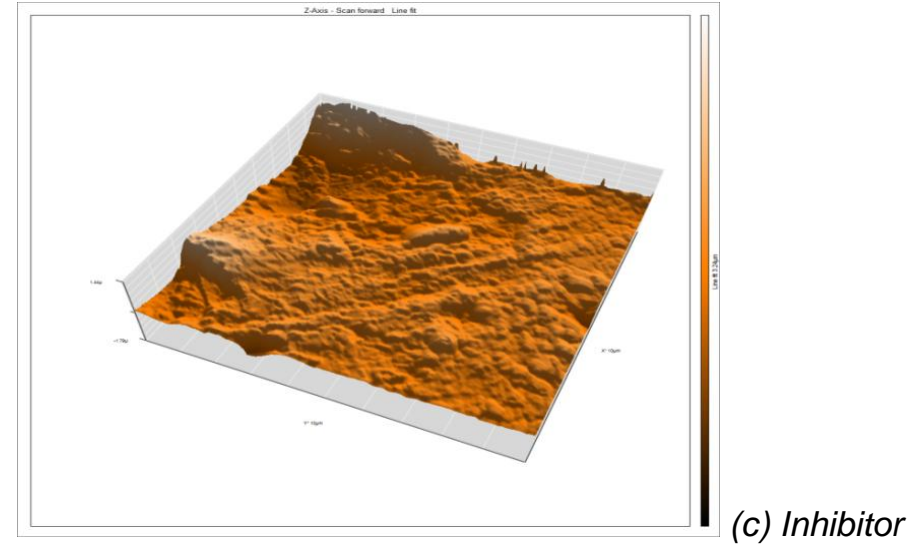

Figure.11. The 3D of optical images of AFM in free sample of metal (a) and blank (b) and Esomeprazole Magnesium Trihydrate inhibitor (c)

Slika 11. 3D optičke slike AFM: uzorka metala (a) prazan (b) i sa inhibitorom Esomeprazole Magnesium Trihydrate (c)

\subsection{FTIR Analysis}

Figure 12 shows the FTIR spectra of the Esomeprazole Magnesium Trihydrate drug. The finger print spectra of the drug and the MS surface after immersion in $1 \mathrm{M} \mathrm{HCl}+60 \mathrm{ppm}$ of Esomeprazole Magnesium Trihydrate was obtained and compared to each other it was obviously clear that the same finger print of meloxicam stock solution present on MS surface except the absence of some functional group and it suggested to be due to reaction with $\mathrm{HCl}$. From Figure there are small shift in the peaks at MS surface from the original peak of the stock inhibitor solution, these shifts indicate that there is interaction between MS and some of the inhibitor's molecules.

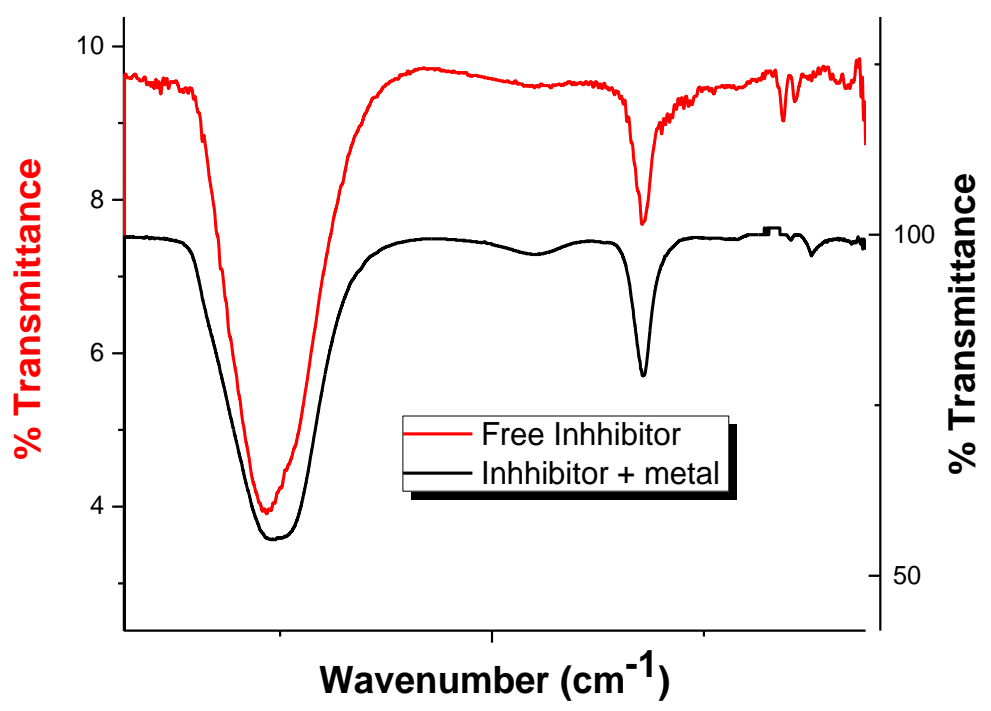

Figure 12. FTIR spectra of the Esomeprazole Magnesium Trihydrate drug

\section{Slika 12. FTIR spektri leka Esomeprazole Magnesium Trihydrate}

\subsection{Mechanism of Corrosion Inhibition}

The inhibition mechanism includes the inhibitor adsorption on the MS surface dipped in aqueous $\mathrm{HCl}$. Four natures of adsorption [55] may occurring contain organic molecules at the interface among MS/solution interface: 1) Electrostatic attraction among the charged metal and the charged molecules; 2) Interaction of unshared electron pairs in the molecule through the metal; 3) Interaction of $\pi$-electrons with the metal; 4) Summation of all the above. From the observations drawn from the various tests, corrosion protection of $\mathrm{MS}$ in $1 \mathrm{~N} \mathrm{HCl}$ solutions by Esomeprazole Magnesium Trihydrate as designated from WL, PP and EIS tests were found to rely on the dose and the nature of the protection. Molecules of the Esomeprazole 
Magnesium Trihydrate can suppress anodic and cathodic processes either by physisorption or by chemisorption, where interactions of metal and inhibitors may due to electrostatic interaction or electron transfer process, respectively. Moreover, the negative value of $\Delta \mathrm{G}^{\circ}$ ads with the range -29.7 to $-40.8 \mathrm{~kJ} \mathrm{~mol}^{-1}$ confirms the spontaneous adsorption of the drug on MS surface by both physisorption and chemisorption processes. In the acid medium the drug molecules may be protonated or may be neutral. Physisorption mechanism is due to: In the acid medium the drug molecules are protonated so, there is difficult for these protonated molecules to adsorb on the positive MS surface [56]. Chloride ions get first adsorbed on MS surface, the MS surface becomes negatively charged, and then the protonated Esomeprazole Magnesium Trihydrate molecules get adsorbed on the chloride layer. Chemisorption mechanism is due to: the neutral molecules can be adsorbed onto the MS surface via electron transfer from adsorbed species to the vacant electron orbital of low energy in the metal to form co-ordinate link.

A comparative study showing IE performance of some of the drugs reported before in the literature is illustrated in Table 7. The present drug shows considerably significant corrosion protection compared to some other drugs. Thus, it can be clearly understood that the present drug (Esomeprazole Magnesium Trihydrate) can be used for corrosion inhibition application with promising results. The higher inhibition efficiency of the investigated drug can be explained on the basis of strong interaction between metal and drug molecules through several polar groups (such as $\mathrm{SO}_{2}, \mathrm{C}=\mathrm{O}$ ), heteroatoms $(\mathrm{N}, \mathrm{O}, \mathrm{S})$, and aromatic as well as hetero-aromatic rings.

Table 7. A comparative chart listing the performance s of some drugs as corrosion inhibitors for MS in acidic solutions

Tabela 7. Uporedna lista u kojoj su navedene performanse nekih lekova kao inhibitora korozije za MS u kiselim rastvorima

\begin{tabular}{|l|c|c|c|}
\hline \multicolumn{1}{|c|}{ Drug } & medium & $\mathrm{IE} \%$ & Reference \\
\hline Penciillin $\mathrm{G}$ & $\mathrm{H}_{2} \mathrm{SO}_{4}$ & 73.7 & {$[57]$} \\
\hline Penciillin V & $\mathrm{H}_{2} \mathrm{SO}_{4}$ & 63.3 & {$[58]$} \\
\hline Cefalexin & $\mathrm{HCl}$ & 67.5 & {$[59]$} \\
\hline Ceftriaxone & $\mathrm{HCl}$ & 90.0 & {$[60]$} \\
\hline Cefotaxime & $\mathrm{HCl}$ & 90.0 & {$[61]$} \\
\hline Cefixime & $\mathrm{HCl}$ & 90.0 & {$[62]$} \\
\hline Quinoline & $\mathrm{HCl}$ & 88.7 & {$[63]$} \\
\hline $\begin{array}{l}\text { Esomeprazole } \\
\begin{array}{l}\text { Magnesium } \\
\text { Trihydrate }\end{array}\end{array}$ & $\mathrm{HCl}$ & $88-93.2$ & $\begin{array}{c}\text { Present } \\
\text { work }\end{array}$ \\
\hline
\end{tabular}

\section{CONCLUSIONS}

Esomeprazole Magnesium Trihydrate drug was acting as effective inhibitor for $\mathrm{MS}$ in $\mathrm{HCl}$ solution. By analyzing the data it can be noticed that corrosion protection increased with increasing the doses of the drug and with raising the temperature. The adsorption of Esomeprazole Magnesium Trihydrate molecule obeyed Temkin adsorption isotherm. The polarization data revealed that this drug inhibits both anodic and cathodic reactions. The data obtained from different techniques are in good agreement.

\section{REFERENCES}

[1] G.Trabanelli (1991) Inhibitors - an old remedy for a new challenge, Corrosion, 47(6), 410-419.

[2] F.Suedile, F.Robert, C.Roos, M.Lebrini (2014) Corrosion inhibition of $\mathrm{Zn}$ by Mansoa alliacea plant extract in sodium chloride media: Extraction, Characterization and Electrochemical Studies, Electrochim. Acta, 33, 631-638.

[3] R.T.Loto, C.A.Loto, A.P.I.Popoola (2012) Corrosion inhibition of thiourea and thiadiazole derivatives: a review, J. Mater. Environ.Sci., 3, 885-894.

[4] D.G.Ladha, U.J.Naik, N.K.Shah (2013) Investigation of cumin (Cuminum Cyminum) extract as an eco-friendly green corrosion inhibitor for pure Aluminum in acid medium", J. Mater. Environ.Sci 4,701-708.

[5] N.Hajjaji, I.Ricco, A.Srhiri (1993) Lattes A., Soufiaoui M., Benbachir A., Effect of NAlkylbetaines on the Corrosion of Iron in $1 \mathrm{M} \mathrm{HCl}$ Solution, Corrosion, 49, 326-334.

[6] A.S.Fouda, M.Morsi, H.A.Mosallam (2016) Capsicum extract as green corrosion extract for carbon steel in hydrochloric acid solutions,Zastita materijala, 57(1), 33-47.

[7] M.Elachouri, M.S.Hajji, M.Salem, S.Kertit, R.Coudert, E.M. Essassi 1995) some surfactants in the series of 2-(alkyldimethylammonio) alkanol bromides as inhibitors of the corrosion of iron in acid chloride solution, Corros Sci, 37,381-389.

[8] A.S.Fouda, S.A.El-Maksoud, S.A.El-Salam (2017) Mitigation of corrosion of carbon steel in acid medium using some antipyrine derivatives, Zastita materijala, 58(1), 5-17.

[9] H.Luo, Y.C.Guan, K.N.Han (1998) Inhibition of mild steel corrosion by sodium dodecyl benzene sulfonate and Sodium Oleate in Acidic Solutions, Corrosion, 54, 619-627.

[10] A. S.Fouda, A.Y.El-Khateeb, N.M.Elbahrawi (2017) Cupressus sempervirens extract as green inhibitor for corrosion of carbon steel in hydrochloric acid solutions, Zastita materijala, 58(2), 131-145.

[11] M.A.Migahed, E.M.S.Azzam, A.M.Al-Sabagh (2004) Corrosion inhibition of mild steel in $1 \mathrm{M}$ sulfuric acid solution using anionic surfactant, Mater. Chem. Phys, 85, 273-279.

[12] M.M.Osman, A.M.Omar,. A.M.Al-Sabagh (1997) Corrosion inhibition of benzyl triethanol ammonium chloride and its ethoxylate on steel in sulphuric acid solution, Mater Chem Phys, 50, 271- 274.

[13] F.Zucchi, G.Trabanelli, G. Brunoro (1992) the influence of the chromium content on the inhibitive efficiency of some organic compounds, Corros Sci., 33, 1135-1139.

[14] R.F.V.Villamil, P.Corio, J.C.Rubim, M.L.Siliva Agostinho (1999) Effect of sodium dodecylsulfate 
on copper corrosion in sulfuric acid media in the absence and presence of benzotriazole, $J$ Electroanal Chem, 472,112-119.

[15] T.P.Zhao, G.N.Mu (1999) The adsorption and corrosion inhibition of anion surfactants on aluminum surface in hydrochloric acid, Corros Sci., 41,1937-1944.

[16] S.S.Abd El Rehim, H. Hassan, M.A. Amin (2001) Corrosion inhibition of aluminum by 1,1 (lauryl amido)propyl ammonium chloride in $\mathrm{HCl}$ solution, Mater Chem Phys., 70, 64-72.

[17] S.S.Abd El Rehim, H.Hassan, M.A.Amin (2003) The corrosion inhibition study of sodium dodecyl benzene sulphonate to aluminum and its alloys in $1.0 \mathrm{M} \mathrm{HCl}$ solution, Mater Chem Phys., 78, 337 348.

[18] R.Guo, T.Liu, X.Wei (2002) Effects of SDS and some alcohols on the inhibition efficiency of corrosion for nickel, Colloids Surf, 209, 37-45.

[19] A.S.Fouda, S.M.Rashwan, N.F.El-Aal, N.H.Ramadan (2016) Unused augmentin drug as save corrosion inhibitor for a-brass in nitric acid solution, Zastita materijala, 57(2), 326-339.

[20] A.S.Fouda, S.A.El-Maksoud, H.M.Mostafa (2017) Tilia leafs as eco-friendly corrosion inhibitor for mild steel in aqueous solutions, Zastita materijala, 58(3), 259-271.

[21] V.Branzoi, F.Golgovici, F.Branzoi (2002) Aluminum corrosion in hydrochloric acid solutions and the effect of some organic inhibitors, Mater. Chem. Phys, 78, 122-131

[22] A.S. Fouda, A.H.Ali (2018) Egy- dronate drug as promising corrosion inhibitor of C - steel in aqueous medium, Zastita materijala, 59(1), 126-141.

[23] T.F.Bentiss, M. Lagrenee (2000) the substituted 1, 3, 4-oxadiazoles: a new class of corrosion inhibitors of mild steel in acidic media, Corros Sci., 42,127-146.

[24] M.A.B.Christopher, A.R.Isabel Jenny (1994) the electrochemical behavior and corrosion of aluminium in chloride media. The effect of inhibitor anions, Corros Sci., 36, 915-923.

[25] M.Elachouri, M.Hajji, M.Salem, S.Kertit, J.Aride, R.Coudert, E.Essassi (1996) Some Nonionic Surfactants as Inhibitors of the Corrosion of Iron in Acid Chloride Solutions, Corrosion, 52,103-108.

[26] A.S. Algaber, E.M. El-Nemma, M.M.Saleh (2004) Effect of octylphenol polyethylene oxide on the corrosion inhibition of steel in $0.5 \mathrm{M} \mathrm{H} 2 \mathrm{SO} 4$, Mater Chem Phys, 86, 26-32.

[27] R.Oukhrib, B.El H.Ibrahimi, Bourzi, K. El Mouaden, A. Jmiai, S.El Issami, L.Bammou, L. Bazzi (2017) Quantum chemical calculations and corrosion inhibition efficiency of biopolymer "chitosan" on copper surface in 3\% NaCl, JMES, 8 (1), 195-208.

[28] A.M.Al-Azzawi, K.K.Hammud (2016) newly antibacterial / anti-rusting oxadiazole poromellitic di-imids of carbon steel/hydrochloric acid interface: Temkin isother model, IJRPC, 6(3), 391-402.

[29] L.El Ouasif, I.Merimi, H.Zarrok, M.El ghoul, R. Achour, M.Guenbour, H.Oudda, F. El-Hajjaji , B. Hammouti (2016) Synthesis and inhibition study of carbon steel corrosion in hydrochloric acid of a new surfactant derived from 2-mercaptobenzimidazole, J Mater Environ Sci., 7 (8), 2718-2730.

[30] U.M.Sani, U.U.Sman (2016) Electrochemical Corrosion Inhibition of Mild Steel in Hydrochloric Acid Medium Using the Antidiabetic Drug Janumet as Drug, International Journal of Novel Research in Physics Chemistry \& Mathematics, 3(3), 30-37.

[31] A.M.Kolo, U.M.Sani, U.Kutama, U.Usman (2016) Adsorption and Inhibitive Properties of Januviafor the Corrosion of $\mathrm{Zn}$ in $0.1 \mathrm{M} \mathrm{HCl}$, The Pharmaceutical and Chemical Journal, 3(1),109119.

[32] P.O.Ameh, U.M.Sani (2015) Cefuroxime Axetil: A Commercially Available Pro-Drug as Corrosion Drug for Aluminum in Hydrochloric Acid Solution, Journal of Heterocyclic, 1(1), 2-6.

[33] R.Kushwah, R.K.Pathak (2014) Inhibition of Mild Steel Corrosion in $0.5 \mathrm{M}$ Sulphuric Acid Solution by Aspirin Drug, International Journal of Emerging Technology and Advanced Engineering, 4(7), 880884.

[34] A.S. Fouda, M.N.EL-Haddad, Y.M. Abdallah (2013) Septazole: Antibacterial Drug as a Green Corrosion Drug for Copper in Hydrochloric Acid Solutions, IJIRSET, 2(12), 7073-7085.

[35] S.U.Ofoegbu, P.U.Ofoegbu (2012) Corrosion inhibition of mild steel in $0.1 \mathrm{M}$ hydrochloric acid media by chloroquine diphosphate, ARPN Journal of Engineering and Applied Sciences, , 7 (3), 272 276.

[36] G.N. Mu, T.P.Zhao, M. Liu, T. Gu (1996) Effect of Metallic Cations on Corrosion Inhibition of an Anionic Surfactant for Mild Steel, Corrosion, 52, 853-856.

[37] J.Lipkowski, P.N.Ross (1989) Adsorption of Molecules at Metal Electrodes, VCH, New York.

[38] [32] SLFA Da Costa, S.M.L.Agostinho (1989) Electrochemical studies of Cu-Al Alloys in Sulphate - Sci ELO, Corrosion, 45, 472-477.

[39] J.Aljourani, K.Raeissi, M.A.Golozar (2009) Benzimidazole and its derivatives as corrosion inhibitors formild steel in $1 \mathrm{M} \mathrm{HCl}$ solution, Corros Sci, 51, 1836-1843.

[40] E.S.Ivanov (1986) Inhibitors for Metal Corrosion in Acid Media, Moscow: Metallurgy,

[41] M.Lebrini, F.Bentiss, H.Vezin , M. Lagrenee (2006) The inhibition of mild steel corrosion in acidic solutions by 2, 5-bis (4-pyridyl)-1, 3, 4-thiadiazole: Structure-activity correlation, Corros Sci, 48,12791291.

[42] T.P.Hour, R.D.Holliday (1953) the inhibition by quinolines and thioureas of the acid dissolution of mild steel, J Appl Chem, 3, 502-513.

[43] L.O.Riggs, T.J.Hurd (1967) Temperature Coefficient of Corrosion Inhibition, Corrosion, 23, 252-260.

[44] G.M.Schmid, H.J.Huang (1980) Spectroelectrochemical studies of the inhibition effect of 4 , 7-diphenyl -1, 10-phenanthroline on the corrosion of 304 stainless steel, Corros Sci, 20,1041-1057.

[45] E. Kus, F.Mansfeld (2006) an evaluation of the Electrochemical Frequency Modulation (EFM) Technique, Corros Sci, 48, 965-979.

[46] G.A. Caigman, S.K. Metcalf, E.M.Holt (2000) Thiophene substituted dihydropyridines, J Chem Cryst, 30,415-422. 
[47] El Achouri, S.Kertit, H.M.Gouttaya, B.Nciri Bensouda, L.Perez, M.R.Infante, K.Elkacemi (2001) Corrosion inhibition of iron in $1 \mathrm{M} \mathrm{HCl}$ by some Gemini Y.surfactants in the series of alkanediyl-a, x-bis-(dimethyl tetradecyl ammonium bromide, Prog Org Coat, 43,267-282.

[48] J.R.Macdonald, W.B.Johanson (1987) in: JR Macdonald (Ed), Theory in Impedance Spectroscopy, John Wiley\& Sons, New York.

[49] M.Elachouri, M.S.Hajji, M.Salem, S.Kertit, R. Coudert, E.M.Essassi (1995) Some surfactants in the series of 2-(alkyldimethylammonio) alkanol bromides as inhibitors of the corrosion of iron in acid chloride solution, Corros Sci, 37,381-389

[50] G.Trabanelli, C.Montecelli, V.Grassi, A.Frignani (2005) electrochemical study on inhibitors of rebar corrosion in carbonated concrete, J.Cem Concr Res, 35, 1804-1813.

[51] A.J.Trowsdate, B.Noble, S.J.Haris, I.S.R.Gibbins, G.E. Thomson, G.C. Wood (1996) The influence of silicon carbide reinforcement on the pitting behavior of aluminum, Corros Sci, 38,177-191.

[52] F.M.Reis, H.G.De Melo, I.Costa (2006) EIS investigation on Al 5052 alloy surfacepreparation for self-assembling monolayer, Electrochim. Acta, 51, 1780-1788.

[53] M.Lagrenee, B.Mernari, M.Bouanis, M.Traisnel, F.Bentiss (2002) Study of the mechanism and inhibiting efficiency of 3,5-bis (4-methylthiophenyl)$4 \mathrm{H}-1,2,4$-triazole on mild steel corrosion in acidic media, Corros Sci, 44, 573-588.

[54] E.McCafferty, N.Hackerman (1972) Double Layer Capacitance of Iron and Corrosion Inhibition with Polymethylene Diamines, J.Electrochem Soc, 119,146-154.

[55] H.Ma, S.Chen, N.S.Zhao, S.Li, D.Li (2002) Inhibition of copper corrosion by several Schiff bases in aerated halide solutions, J.Appl Electrochem, 32, 65-72.

[56] A.S.Fouda, H.Ibrahim, M.Atef (2017) Adsorption and inhibitive properties of sildenafil (Viagra) for zinc in hydrochloric acid solution, Results in Physics, 7, 3408-3418.

[57] H.Patmore, A.Jebreel, S.Uppal, C.H.Raine, P.McWhinney (2010) Skull base infection presenting with multiple lower cranial nerve palsies. Am J Otolaryngol, 31(5), 376-380?

[58] G.J.Ridder, C.Breunig, J.Kaminsky, J.Pfeiffer (2015) Central skull base osteomyelitis: new insights and implications for diagnosis and treatment. European archives of oto-rhinolaryngology, 272(5), 1269-1276.

[59] D.H.Kraus, S.J.Rehm, S.E.Kinney (1988) the evolving treatment of necrotizing external otitis. The Laryngoscope, 98(9), 934-939.

[60] M.P.Stokkel, C.N.Boot, B.L.Van Eck-Smit (1996) SPECT gallium scintigraphy in malignant external otitis: initial staging and followup. Case reports. Laryngoscope, 106(3 Pt 1), 338-340.

[61] M.P.Clark, P.M.Pretorius, I.Byren, C.A.Milford (2009) Central or atypical skull base osteomyelitis: diagnosis and treatment. Skull Base, 19(4), 247254.

[62] N.C.Okpala, Q.H.Siraj, E.Nilssen, M. Pringle (2005) Radiological and radionuclide investigation of malignant otitis externa. J Laryngol Otol, 119(1), 71-75.

[63] P. Sharma, K.K.Agarwal, S.Kumar, H.Singh, C. Bal (2013) (Utility of $(99 \mathrm{~m})$ Tc-MDP hybrid SPECT-CT for diagnosis of skull base osteomyelitis: comparison with planar bone scintigraphy, SPECT, and CT., Jpn J Radiol, 31(2), 81-88

\title{
IZVOD
}

\section{LEK ESOMEPRAZOLE MAGNESIUM TRIHYDRATE KAO POTENCIJALNI NEOTROVNI INHIBITOR KOROZIJE ZA MEKI ČELIK U KISELIM MEDIJIMA}

\begin{abstract}
Inhibitorski efekat leka Esomeprazole Magnesium Trihydrate na koroziju mekog čelika (MS) u $1 \mathrm{M}$ $\mathrm{HCl}$ ispitan je hemijskim testovima (gubitak težine (VL)) i elektrohemijskim metodama (Tafelova polarizacija (TP), elektrohemijska frekventna modulacija (EFM) i AC impedansna spektroskopija (EIS)). Otkriveno je da je adsorpciona izoterma leka Esomeprazole Magnesium Trihydrate na površini MS praćena Temkinovom adsorpcionom izotermom. Neki termodinamički parametri su izračunati i diskutovani. Dobiveni podaci pokazali su da se efikasnost inhibicije (IE) povećava s povećanjem koncentracije Esomeprazole Magnesium Trihydrate $i$ povećanjem temperature. Morfologija MS površine analizirana je korišćenjem skenirajućeg elektronskog mikroskopa (SEM), atomske mikroskopije (AFM) i FTIR tehnikom. Rezultati svih metoda ispitivanja bili su u međusobnom slaganju.

KIjučne reči: kisela korozija, meki čelik, SEM, AFM, FTIR, Esomeprazole Magnesium Trihydrate.
\end{abstract}

\author{
Naučni rad \\ Rad primljen: 25. 04. 2019 \\ Rad prihvaćen: 26. 05. 2019. \\ Rad je dostupan na sajtu: www.idk.org.rs/casopis
}

\footnotetext{
(C) 2019 Authors. Published by Engineering Society for Corrosion. This article is an open access article distributed under the terms and conditions of the Creative Commons Attribution 4.0 International license (https://creativecommons.org/licenses/by/4.0/)
} 